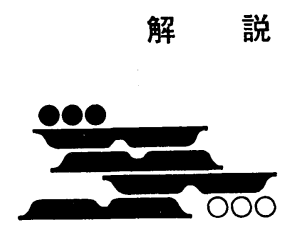

\title{
最近の状態図に関する研究
}

\section{—コンピュータによる状態図の計算 —}

\author{
長谷部 光 弘 ${ }^{*}$ 西 沢 泰 二**
}

\section{1.は じめに}

すべての合金系の状態図を計算によって構成すること はできないだろらか? このような考光は多くの金属学者 の頭の中に幾度となく去来したに違いない，とくに近年 はコンピュータ技術が発達して, 驚くほど高速で精度の よい計算が可能になったのであるから，成分元素につい ての基礎的数值をコンピュータに入力しさえすれば, 即 座に状態図が出打るということができてもよさそうに 思われる. しかしこれはあくまでも理屈であって, 現実 はかなりきびしい. 結論から先に述べるならば,計算のみ によって状態図が構成されるようになるためにはまだま だ基礎的データが不足しており，これまでに行なわれて さたよりもさらに多くの実験研究が必要のようである.

そもそも状態図は, その系の熱力学的性質の一つの表 現であるから, 原理的には熱力学的計算によって構成で きるはずのものである.Van Laar(1) はすでに 1908 年, 正則溶体近似法を用いて 2 元系の各相の自由エネルギー を記述することにより, 共晶, 共析, 包晶, 包析, 偏晶, 2 相分離, スピノーダル分解などの各種の反応の現われ る基本的 2 元系状態図を構成することがでさることを示 した. 同様の研究は本邦においても多くなされ，とくに 高木, 長崎 ${ }^{(2)}$ の報告は著名である。この種の状態図はい わば “理論状態図”であって，実際の合金の状態図とは おのずから類を異にする.むしろ理論状態図は実際の状 態図の熱力学的な理解を助けるための説明役として用い られてきたのが普通であった ${ }^{(3)}$ (4).

しかしながら状態図は実験だけによって構成すべきも のと断言することは間違いであろう．実験のおよぶ範囲 は限られて拉り,たとえば拡散の活発でないよらな温度

* 東北大学大学院学生

** 東北大学教授; 工学部金属材料工学科

(1) J.J.Van Laar: Z.Phys. Chem., 63(1908), 216 ; $64(1908), 257$.

（2）高木, 長崎：金属学会分科会報告, 第无集, (1947), 1.

(3) A.H.Cottrell: Theoretical Structural Metallurgy, Edward Arnold, London, (1948).

(4) Thermodynamics in Physical Metallurgy, Am. Soc.Metals, Cleveland, Ohio, (1950).

(5) L.S.Darken and R.W.Gurry: Trans.Met.Soc. AIME, 191 (1951), 1015.
に拈ける平衡関係を実測することはできないしまな $2000^{\circ} \mathrm{C}$ を越えるような高温度における相平衡について 実験することもきわめて困難であることからわかるよう に, 実験結果だけに基づいた状態図，ここでは “実験状 態図”と呼ぶことにするが，それは真実の状態図の一部 分にしかすぎないことは明白である。

結局, われわれが本当に必要な真実の状態図は, 正確 な実験に支えられた理論状態図であることが望ましい. それは理論的であるがために実験不可能な組成域や温度 域に拈ける平衡関係, さらには相変態の問題を考えると きに重要な準安定平衡をも示すことができ，しかも実験 に支えられているがために高い信頼度で相関係を明示す ることができるからである．このような理論と実験とを かみ合わせた構成法による状態図の研究はおよそ 20 年 前から二, 三のグループによって推進されてきた。 とく に Darken, Gurry ${ }^{(5)}$, Benz, Elliott(6) らが構成した Fe-C 系状態図(第 1 図) は実験状態図の域を脱却して, しかも 広く一般に採用されるようになった先駆的なものであ


にしたヨーロッパ各国に拉ける忍耐づよい研究も見逃す わけにはいかない。

理論と実験とをかみ合わせて状態図を構成する場合の 一つの险路は繁雑な数値計算にあった. 一般に平衡関係 を規定する方程式は単純な解を持たないので, trial and error 的な計算を行なわなければならず, 熱力学データ をより忠実に反映させようと心がければますます計算が 複雑になる. しかし, この問題は近年のコンピュータの 発達と普及によって一挙に解決され, 各所でュンピェー タによる状態図の解析が行なわれはじめた.とくに Rudman $^{(9)}$ や Kaufman, Bernstein ${ }^{(10)}$ の研究は価値ある

(6) M.G.Benz and J.F.Elliott : Trans. Met. Soc. AIME, 221 (1961) , 323.

(7) J.L.Meijering : Acta Met., 5(1957), 257.

(8) O.Kubaschewski and T.G.Chart: J.Inst.Metals, 93 $(1964 / 5), 329$.

(9) P.S.Rudman : Advances in Materials Research, Vol.4, Ed. by H.Herman, Interscience Pub., (1970), 147.

(10) L.Kaufman and H.Bernstein : Computer Calculation of Phase Diagrams, Academic Press, New York, (1970). 


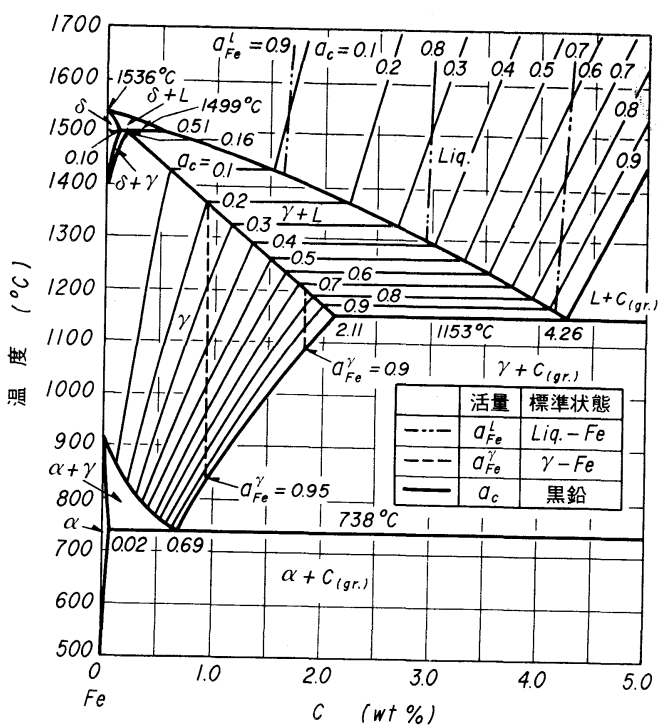

第 1 図 Fe-C 2 元系の状態図と等活量線図

もので, 2 元系や 3 元系の状態㘠を計算するためのプロ グラムを発表している。これらはまだ十分なものとはい えないが, 将来は熱力学的なすべての情報をコンピュー タに記憶させて置き，いつでも必要な状態図がただちに 入手でさるようになろう。

では具体的に状態図の計算はどうしたらできるのだろ らか, 現在わが国においては主要大学や研究所に大型電 子計算機が設置され，この処理能力も年々増大してい る、しかしこれを利用するとき，プログラミングのすべ てを職業的なプログラマにまかせられるような環境では ない，そこで本稿では状態図計算の方法をいくつかの例 を挙げて解説することにした。

\section{2. 固溶体の自由エネルギー関数}

相平衡(状態図)を熱力学的に計算するには，まず各相 の Gibbs 自由エネルギーを温度，組成，圧力などの関数 として表わさなければならない。最近は超高圧発生技術 の発達とともに相平衡への圧力の影響についてもかなり 研究されはじめているが(56)(67)(68)，ここでは自由エネル ギーを温度と組成との関数として取扱らことにする.

いま A-B 2 元系置換型固溶体の $1 \mathrm{~g}$ 一原子あたりの自

(11) E.A.Guggenheim : Mixture, Clarendon Press, Oxford, (1952) .

(12) J.C. Mathieu, F.Durand and E.Bonnier : J. Chim.Phys., 62(1965) , 1289, 1297.

(13) P. Hicter, J. G. Mathieu, F. Durand and E. Bonnier : J.Chim. Phys., 64 (1967), 261.

(14) B.Brion, J.C.Mathieu, P.Hicter and P.Desre: J.Chim.Phys., 66 (1969), 1238.

(15) B.Brion, J.C.Mathieu and P.Desre : J.Chim. Phys., 67 (1970), 1745.

(16) C.H.P.Lupis and J.F.Elliott : Acta Met., 14 (1966), $529 ; 15$ (1967), 265.
由エネルギー $G$ にいて考えると，一般に

$$
\begin{aligned}
G= & { }^{\circ} G_{\mathrm{A}} x_{\mathrm{A}}+{ }^{\circ} G_{\mathrm{B}} x_{\mathrm{B}} \\
& +R T\left(x_{\mathrm{A}} \ln x_{\mathrm{A}}+x_{\mathrm{B}} \ln x_{\mathrm{B}}\right)+{ }^{\mathrm{Ex}} G
\end{aligned}
$$

と表わされる。ここで ${ }^{\circ} G_{i}$ は $T{ }^{\circ} \mathrm{K} に$ に打る純粋 $i$ 成分 の $1 \mathrm{~g}$ 一原子あたりの自由エネルギー， $x_{i}$ は原子分率であ る. また ${ }^{\mathrm{EX}} G$ は理想溶体からのずれを表わす過剰自由エ ネルギーであり, 正則溶体近似ではよく知られているよ らに

$$
\mathrm{EX}_{G}=Q_{\mathrm{AB}} x_{\mathrm{A}} x_{\mathrm{B}}
$$

となる、 $\Omega_{\mathrm{AB}}$ は相互作用パラメータで単純な正則溶体で は温度や組成によらない定数である。

一般に $N$ 元系固溶体の正則溶体近似では

$$
\begin{aligned}
& G=\sum_{i=1}^{N}{ }^{\circ} G_{i} x_{i}+R T \sum_{i=1}^{N} x_{i} \ln x_{i}+{ }^{\mathrm{Ex}_{G}} \\
& \mathrm{EX}_{G}=\sum_{i=1}^{N-1} \sum_{j=i+1}^{N} \Omega_{i j} x_{i} x_{j}
\end{aligned}
$$

と表わされる， $Q_{i j}$ は $i-j 2$ 元系に打将る相互作用パラ メータであり, 単純正則溶体では $\Omega_{i j}$ は温度, 組成によ らない定数なので 2 元系のパラメータだけを知っておれ ば多元系の自由エネルギーが得られる.

置換型固溶体の理論的モデルとしては準化学的モデ ル(11), Surrounded Atom モデル(12) (15), Central Atom Theory(16) などがある。これらはいずれも最隣接原子間 の相互作用を考孚るモデルである．しかしどのモデルも 真実の自由エネルギーを正確に表わすには不十分であ る. そこでコンピュータ解析を目的とする場合には相互 作用パラメータに温度や組成依存性を考㝋

$$
\Omega_{\mathrm{AB}}=A_{0}+A_{1} x_{\mathrm{B}}+A_{2} x_{\mathrm{B}}^{2}+\cdots \cdots+A_{n} x_{\mathrm{B}}^{n}
$$

のようにべき乗級数で近似する。. $A_{0}, A_{1}, \cdots, A_{n}$ はそれぞ れ温度の関数とする。この種の表わし方は Margules ${ }^{(17)}$ によって用いられたが, Guggenheim(18) は対称性のよい 表わし方として次式を用いた.

$$
\begin{aligned}
\Omega_{\mathrm{AB}}= & B_{0}+B_{1}\left(x_{\mathrm{B}}-x_{\mathrm{A}}\right)+B_{2}\left(x_{\mathrm{B}}-x_{\mathrm{A}}\right)^{2} \\
& +\cdots+B_{n}\left(x_{\mathrm{B}}-x_{\mathrm{A}}\right)^{n}
\end{aligned}
$$

この他にも種々の表示法が多くの研究者によって提案さ れているが(19) (24) (114) (128)，実験值を忠実に表わすには

(17) M.Margules : Sitzber. Akad. Wiss. Wien, 104 (1895) , 1243.

(18) E. A. Guggenheim : Trans. Faraday Soc., 33 (1937) , 151.

(19) G.Borelius : Ann.Physik., Series 5, 20 (1934), 57.

(20) C.Wagner : Thermodynamics of Alloys, Addison Wesley, Cambridge, Mass., (1952).

(21) R. O. Williams : Trans. Met. Soc. AIME, 245 (1969) , 2565

(22) H.K.Hardy : Acta Met., 1(1953) , 202; 2(1954), 348.

(23) J.D.Esdaile : Met.Trans., 2(1971), 2277.

(24) R.L.Sharkey, M.J.Pool and M.Hoch : Met. Trans., 2(1971), 3039. 
（5）または（6）式が適当であろう.

ただし， 3 元以上の多元系の過剩自由エネルギーを表 わす場合には， 2 元系の場合のように相互作用パラメー タの組成依存性までも包含した $(5)$ または (6)式を直接 (4) 式に代入するわけにはいかないことに注意が必要で ある.たとえばA-B 2 元系の相互作用パラメータとし $\tau$

$$
\Omega_{\mathrm{AB}}=A_{0}+A_{1} x_{\mathrm{B}}
$$

を考光よう。これは $x_{\mathrm{A}}+x_{\mathrm{B}}=1$ であるから

$$
\Omega_{\mathrm{AB}}=\left(A_{0}+A_{1}\right)-A_{1} x_{\mathrm{A}}
$$

とも書ける. しかし多元系においては $x_{\mathrm{A}}+x_{\mathrm{B}}<1$ であ るので (4) 式に $Q_{\mathrm{AB}}$ を入れた場合, (7-1) と(7-2)式とで は異なった值となる。 そこでこのような場合には，さら に新たなパラメータを導入し $D x_{\mathrm{A}} x_{\mathrm{B}} x_{\mathrm{C}}$ のような高次の 項が必要となる. Margules 形の式を一般的に書くと過 剩自由エネルギーは

$$
\mathrm{Ex}_{G}=\sum_{i j} A_{i j} x_{i} x_{j}+\sum_{i j k} A_{i j k} x_{i} x_{j} x_{k}+\cdots
$$

となる(114).ここで，たとえば $\sum_{i j k} A_{i j k} x_{i} x_{j} x_{k}$ とは

$$
\begin{gathered}
\sum_{i=1}^{N} \sum_{j=1}^{N} \sum_{k=1}^{N} A_{i j k} x_{i} x_{j} x_{k}, A_{i j k}=A_{j k i}=\cdots=A_{k i j}, \\
A_{i i i}=A_{j j j}=\cdots=0
\end{gathered}
$$

の意味である. 同様の主旨の経験式としてはWohl の式 などがある(25)〜(32) (114) (128).

以上のように Margules 形の表わし方は実験值を忠実 に記述するのには適している. しかし $N$ 元系に対して は, 2 元系はもちろんのこと, 3 元系, 4 元系, $\cdots, N$ 元系のデータが全部のパラメータを決めるために必要で ある.これに対して 2 元系の值のみから多元系の值を予 測しようとする方法がある ${ }^{(33) \sim(37)(97)}$.このうち Kohler の式 ${ }^{(35)}$ は,

$$
\mathrm{Ex}_{G}=\sum_{i=1}^{N-1} \sum_{j=i+1}^{N}\left(x_{i}+x_{j}\right)^{2}\left(\mathrm{Ex}^{\mathrm{E}_{i j}}\right)_{x_{i} / x_{j}}
$$

と表わされる。ここで $\left(\mathrm{Ex}_{G_{i j}}\right)_{x_{i} / x_{j}}$ は $x_{i} / x_{\mathbf{j}}$ が一定なとさ の $i-j 2$ 元系の過㮃自由エネルギーであり, 3 元系の場 合について図示したのが第2 図である.この(9)式は単 純正則溶体近似の $(4)$ 式を変形して導びかれる. Olson

(25) K. Wohl : Trans. Amer. Inst. Chem. Eng., 42 (1946) , 215.

(26) J.J.Van Larr : Z.Phys.Chem., (1913), 599.

(27) G. Scatchard and W. J. Hammer : J. Amer. Chem.Soc., 7(1935) , 1805.

(28) M.Benedict, C.A.Johnson, E.Solomon and L.C. Rubin : Trans.Amer.Inst.Chem.Eng., 41 (1945), 371.

(29) G.W. Wilson : J.Amer. Chem. Soc., 86 (1964), 127.

(30) R.V.Orye and J.M.Prausnitz: Ind.Eng.Chem., $57(1965), 18$.

(31) E.Bonnier, P.Desre and F.Durand:C.R.Acad. Sci., 250 (1960), 2049.

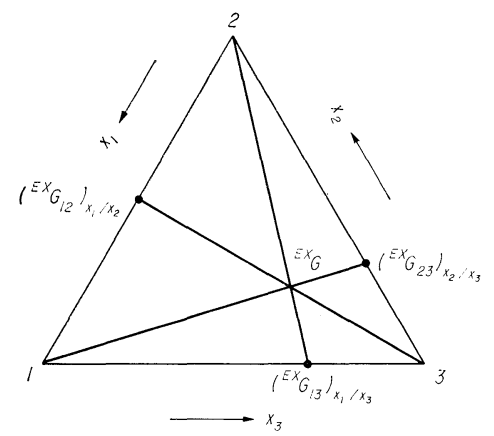

第 2 図 Kohler の式に拈る 2 元系と 3 元系 過利自由エネルギーの関係

と Toop ${ }^{(36)(97)}$ はこれを非正則溶体にも適用し 2 元系の 值から 3 元系怙よび 4 元系の過剩自由エネルギーを計算 した.この（9)式を数値計算に用いる場合には，（5)式 を

$$
\begin{aligned}
\Omega_{i j}= & A_{0}+A_{1} y_{j}+A_{2} y_{j}^{2}+\cdots \cdots+A_{n} y_{j}^{n}, \\
& y_{j}=x_{j} /\left(x_{i}+x_{j}\right)
\end{aligned}
$$

と組成変換し，(4)式に代入すればよい。

(9)式のような予測式は注とんど単純な正則溶体近似 式から出発しており, これらが非正則溶体にも成立する という理論的根拠は何もない. しかしこのように多元系 の熱力学的值が低次元の值で近似できるならば, 熱力学 的研究の上でも，またこれらデータをコンピュータに記 憶させ利用するといら点でも便利である.

これまで述べてきたのはすべて置換型固溶体の自由エ ネルギーについてであった，侵入型固溶体に対して上記 の式は戦密には用いられない，しかし，一般に侵入型元 素の固溶度は非常に小さいことを考えると理想混合のエ ントロピーは近似的に(3)式と同じ形で書くことがで き(128), さらに熱力学データが置換型の正則溶体近似式 を用いて整理されることも知られている(38)(131). このこ とはある程度の厳密性は欠くが, 状態図の計算が置換型, 侵入型合金の区別なく同じ式を用いて行なえるといら利 点がある.そこでここでは侵入型固溶体についての説明 は特に行なわない。詳しくは前揭の文献 ${ }^{(128)}$, さらには 正則溶体近似を侵入型固溶体や非化学量論相に拡張した Hillert ら ${ }^{(39)}$ の論文などを参照されたい.

(32) G.Scatchard : Chem.Rev., 8 (1931), 321.

(33) E.Bonnier and R.Caboz : C.R.Acad.Sci., 250 (1960), 527.

(34) G.W.Toop : Trans.Met.Soc.AIME, 233 (1965), 850.

(35) F.Kohler : Monat.für Chemie, 91 (1960), 738.

(36) N.J.Olson and G.W. Toop : Trans. Met. Soc. AIME, $236(1966), 590$.

(37) C.Colinet:D.E.S., Fac.des Sci., Univ.Grenoble, France, (1967) .

(38) R.P.Smith: J.Amer.Chem.Soc., 68 (1946), 1163.

(39) M.Hillert and L.I.Staffansson : Acta Chem. Scand., 24 (1970) , 3618. 


\section{3. コンピュータによる相平衡の計算法}

状態図を計算するといらことは，結局のところ相平衡 を計算することで，たとえば $\alpha$ との 2 相を考学ると き, 互いに平衡する組成 $\left(x_{1}^{\alpha}, x_{2}^{\alpha}, \cdots, x_{N}^{\alpha}\right)$ と $\left(x_{1}^{\beta}, x_{2}^{\beta}, \cdots, x_{N}^{\beta}\right)$ の組を求めることである.この種の計算の多くは等温と いら条件の下で行なわれるので，以下でもこの条件にお ける計算法についていくつか説明する。

\section{（1）化学ポテンシャルについての連立方程式を解く} 方法

$\alpha$ と $\beta$ の 2 相が平衡する条件は 2 元系の場合第 3 図の ように二つの自由エネルギー曲線へ共通接線を描けるこ とであり，3元系になるとこの条件は共通接平面が描け ることで, 各相の自由エネルギー曲線または曲面との接 点が求める平衡組成の組である.

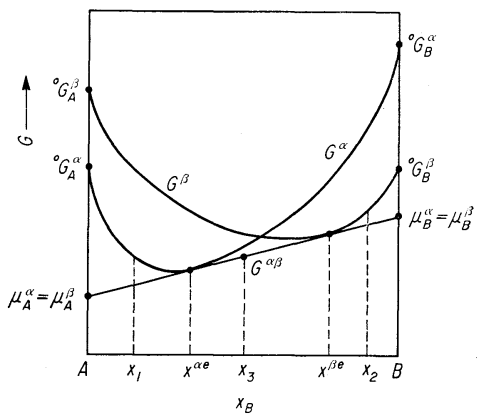

第3 図 A-B 2 元系における自由エネルギー 組成曲線

この条件は一般に

$$
\begin{aligned}
& \mu_{1}^{\alpha}=\mu_{1}^{\beta} \\
& \mu_{2}^{\alpha}=\mu_{2}^{\beta} \\
& \cdots \cdots \cdots \\
& \mu_{N}^{\alpha}=\mu_{N}^{\beta}
\end{aligned}
$$

と表わされ, 相平衡の計算は(11)式の連立方程式を解く ことである. ここで $\mu_{i}$ は $i$ 成分の化学ポテンシャルで, 次式から求められる。

$$
\mu_{i}=G+\sum_{j=1}^{N-1}\left(\delta_{i j}-x_{j}\right) \frac{\partial G}{\partial x_{j}}
$$

$\delta_{i j}$ は $i=j$ のとき $1, i \neq j$ のとき0である. (3) 式を(10) 式に代入すれば

$$
\mu_{i}={ }^{\circ} G_{i}+R T \ln x_{i}+{ }^{{ }^{E x} \bar{G}_{i}}
$$

となり, ${ }^{\mathrm{Ex}} \bar{G}_{i}$ は $i$ 成分の部分モル過剩自由エネルギー で, 化学ポテンシャルと同じ式から計算でき，単純な正 則溶体近似(( 4$)$ 式)の場合

$$
{ }^{\operatorname{Ex}_{G_{i}}}=\sum_{j=1}^{N} \delta_{i j} \Omega_{i j}\left(1-x_{i}\right) x_{j}-\sum_{i=1}^{N-1} \sum_{k=j+1}^{N} \delta_{i j} \cdot \delta_{i k} Q_{i k} x_{j} x_{k}
$$

となる. $\delta_{i j}, \delta_{i k}$ は(12)式の場合と同じ意味である.
A-B 2 元系の場合は

$$
\begin{aligned}
& { }^{{ }^{{ }^{2}} \bar{G}_{\mathrm{A}}}=\Omega_{\mathrm{AB}} x_{\mathrm{B}}^{2} \\
& { }^{{ }^{\mathrm{Ex}} \bar{G}_{\mathrm{B}}}=\Omega_{\mathrm{AB}}\left(1-x_{\mathrm{B}}\right)^{2}
\end{aligned}
$$

となる。また $\Omega_{\mathrm{AB}}$ が(5)または(6)式のように組成依 存性があるときは

$$
\begin{aligned}
& { }^{\mathrm{Ex}_{\bar{G}}} \bar{G}_{\mathrm{A}}=\left(\Omega_{\mathrm{AB}}-\left(1-x_{\mathrm{B}}\right) \frac{\partial \Omega_{\mathrm{AB}}}{\partial x_{\mathrm{B}}}\right) x_{\mathrm{B}}^{2} \\
& { }^{\mathrm{Ex}_{\bar{G}_{\mathrm{B}}}}=\left(\Omega_{\mathrm{AB}}+x_{\mathrm{B}} \frac{\partial \Omega_{\mathrm{AB}}}{\partial x_{\mathrm{B}}}\right)\left(1-x_{\mathrm{B}}\right)^{2}
\end{aligned}
$$

となる、

もっとも簡単な例として A-B 2 元系の $\alpha, \beta$ 両相が共 に理想溶体の場合を考学よう。このとき $\Omega_{\mathrm{AB}}^{\alpha, \beta}=0$ である から(11),(13)式より

$$
\begin{aligned}
& \frac{1-x_{\mathrm{B}}^{\alpha}}{1-x_{\mathrm{B}}^{\beta}}=\exp \frac{{ }^{\circ} G_{\mathrm{A}}^{\beta}-{ }^{\circ} G_{\mathrm{A}}^{\alpha}}{R T}=K_{\mathrm{A}}^{\alpha / \beta} \\
& \frac{x_{\mathrm{B}}^{\alpha}}{x_{\mathrm{B}}^{\beta}}=\exp \frac{{ }^{\circ} G_{\mathrm{B}}^{\beta}-{ }^{\circ} G_{\mathrm{B}}^{\alpha}}{R T}=K_{\mathrm{B}}^{\alpha / \beta}
\end{aligned}
$$

ある温度 $T$ では $K_{\mathrm{A}}^{\alpha / \beta}$ および $K_{\mathrm{B}}^{\alpha / \beta}$ は一定であるから，

(17)式は簡単な連立 1 次方程式として扱らことができて

$$
\begin{aligned}
& x_{\mathrm{B}}^{\alpha}=\frac{K_{\mathrm{B}}^{\alpha / \beta}\left(K_{\mathrm{A}}^{\alpha / \beta}-1\right)}{K_{\mathrm{A}}^{\alpha / \beta}-K_{\mathrm{B}}^{\alpha / \beta}} \\
& x_{\mathrm{B}}^{\beta}=\frac{K_{\mathrm{A}}^{\alpha / \beta}-1}{K_{\mathrm{A}}^{\alpha / \beta}-K_{\mathrm{B}}^{\alpha / \beta}}
\end{aligned}
$$

を得る。

しかし実在系の場合は理想溶体として近似できる系は ほとんどない。このとき(11)の連立方程式を厳密に解 くことは不可能で, 逐次近似法によって数値計算を行な $\zeta^{(40)(41)}$. 簡単のため 2 元系の場合について述べよう.

(11)式の連立方程式を何らかの方法で

$$
\begin{aligned}
& x=f(x, y) \\
& y=g(x, y)
\end{aligned}
$$

の形に書けたとする。適当な初期值 $\left(x^{(0)}, y^{(0)}\right)$ から始め $\tau$, 反復演算

$$
\begin{aligned}
& x^{(n+1)}=f\left(x^{(n)}, y^{(n)}\right) \\
& y^{(n+1)}=g\left(x^{(n)}, y^{(n)}\right)
\end{aligned}
$$

を繰返し， $\lim _{n \rightarrow \infty}\left(x^{(n)}, y^{(n)}\right)$ として根を求めるのである. その方法として基本的なもの二つについて説明する。

\section{(i) Gauss-Seidel 法}

A-B 2 元系の $\alpha, \beta 2$ 相平衡を考㝋る. $\alpha, \beta$ 各相の組 成をとれぞれ $x, y$ とすると，(11)，(13)式より(17)式と 同様の形

$$
\begin{aligned}
& \frac{x_{\mathrm{A}}}{y_{\mathrm{A}}}=\exp \frac{{ }^{\circ} G_{\mathrm{A}}^{\beta}-{ }^{\circ} G_{\mathrm{A}}^{\alpha}+{ }^{\mathrm{Ex}} \bar{G}_{\mathrm{A}}^{\beta}-{ }^{\mathrm{Ex}} \bar{G}_{\mathrm{A}}^{\alpha}}{R T}=K_{\mathrm{A}}^{\alpha / \beta} \\
& \frac{x_{\mathrm{B}}}{y_{\mathrm{B}}}=\exp \frac{{ }^{\circ} G_{\mathrm{B}}^{\beta}-{ }^{\circ} G_{\mathrm{B}}^{\alpha}+{ }^{\mathrm{Ex}} \bar{G}_{\mathrm{B}}^{\beta}-{ }^{\mathrm{Ex}} \bar{G}_{\mathrm{B}}^{\alpha}}{R T}=K_{\mathrm{B}}^{\alpha / \beta}
\end{aligned}
$$

(40) A.D.Booth: Numerical Methods, London, (1955). 宇田川, 中村訳 : 数值計算法, コロナ社.

(41) 宇野: 電子計算機のための数值計算, 朝倉畫店, (1961) . 
が得られる，この場合 ${ }^{\mathrm{Ex}} \bar{G}_{i}$ は組成の関数であるから， $K_{i}^{\alpha / \beta}$ 女また組成の関数である。これをさらに

$$
\begin{aligned}
& x_{\mathrm{A}}=\left(1-y_{\mathrm{B}}\right) \cdot K_{\mathrm{A}}^{\alpha / \beta} \\
& y_{\mathrm{B}}=\left(1-x_{\mathrm{A}}\right) / K_{\mathrm{B}}^{\alpha / \beta}
\end{aligned}
$$

と変形する。 そこで具体的な計算はまず適当な近似值 を $x_{\mathrm{A}}, y_{\mathrm{B}}$ 選ぶ.この值を用いて (21-1)から $K_{\mathrm{A}}^{\alpha / \beta}$ を計算 し，(22-1)より $x_{\mathrm{A}}$ の第 2 近似值を計算する。.つぎに新 しい $x_{\mathrm{A}}$ と $y_{\mathrm{B}}$ から (21-2)を用いて $K_{\mathrm{B}}^{\alpha / \beta}$ を計算し，(222)より $y_{\mathrm{B}}$ の第 2 近似值を計算する。 これを $x_{\mathrm{A}}, y_{\mathrm{B}}$ が一 定になるまで繰返す。これはHillert(128)が用いた方法で ある.この方法では(22)式と別に次のような反復演算も 考えられる.

$$
\begin{aligned}
& y_{\mathrm{A}}=\left(1-x_{\mathrm{B}}\right) / K_{\mathrm{A}}^{\alpha / \beta} \\
& x_{\mathrm{B}}=\left(1-y_{\mathrm{A}}\right) \cdot K_{\mathrm{B}}^{\alpha / \beta}
\end{aligned}
$$

このいずれが適当かを厳密に説明することはできない が， $x$ 打よび $y$ が根に近いときには一般に $K_{i}^{\alpha / \beta}$ は組成 の変化に対してあまり大きく変わらず注ぼ定数とみなせ て，(21) 式は連立 1 次方程式と同等となり，係数の絶対 值の和が 1 より小さければ根に収束することがわか る(41). そこで今の場合も $K_{\mathrm{A}}^{\alpha / \beta}$ が 1 よりさいときは (22)式，1より大きいときは(23)式を用いるべきであろ 5 .

3 元以上の場合も全く同様に計算することができる.

\section{(ii) Newton-Raphson 法}

ある反復演算 $x^{(n+1)}=g\left(x^{(n)}\right)$ において,$x^{(n)}$ が真の值 から小さな值 $\varepsilon$ 程度だけの違いをもつとき， $x^{(n+1)}$ の誤 差が $\varepsilon^{k}$ の程度ならばこの反復法は $k$ 位であるといわれ る. もっともよい反復法は 2 位のものが多く, ここで説 明する方法もこの 2 位の反復法である. (11)式の解法を 説明する前に，まず 1 元高次方程式

$$
f(x)=0
$$

について考えよう. ある近似值 $x^{(n)}$ が得られ, その誤差 が $\varepsilon^{(n)}$ であるとすれば

$$
f\left(x^{(n)}+\varepsilon^{(n)}\right)=0
$$

であるから, Taylor 展開して

$$
\begin{aligned}
f\left(x^{(n)}\right. & \left.+\varepsilon^{(n)}\right)=0=f\left(x^{(n)}\right) \\
& +\varepsilon^{(n)} f^{\prime}\left(x^{(n)}\right)+\frac{\left(\varepsilon^{(n)}\right)^{2}}{2} f^{\prime \prime}\left(x^{(n)}\right)
\end{aligned}
$$

となり, 2 次以上の項を無視して

$$
x^{(n+1)}=x^{(n)}+\varepsilon^{(n)}=x^{(n)}-f\left(x^{(n)}\right) / f^{\prime}\left(x^{(n)}\right)
$$

とすれば, $x^{(n+1)}$ の誤差は $\left(\varepsilon^{(n)}\right)^{2}$ 程度となる. この反復 法を図示したのが第4 図である.

つぎに実際の $N$ 元系に拈ける相平衡について考充よ 5.（i）の場合も同様であったが，3元系以上の昜合は 方程式の数 $N$ と求めようとする未知数の数 $M=2 N-2$ は等しくなく $M>N$ である。この場合には $M=N$ にな るようにいくつかの成分組成を一定にして(11)式を解

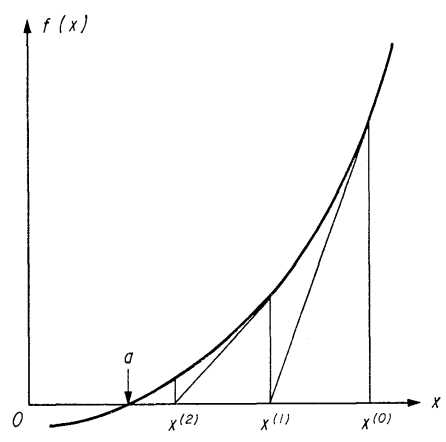

第 4 図 1 元高次方程式の Newton-Raphson 法による解法

く. (11) 式を変形して

$$
\begin{gathered}
f_{1}\left(x_{1}, x_{2}, \cdots, x_{N}\right)=\mu_{1}^{\beta}-\mu_{1}^{\alpha}=0 \\
f_{2}\left(x_{1}, x_{2}, \cdots, x_{N}\right)=\mu_{2}^{\beta}-\mu_{2}^{\alpha}=0 \\
\cdots \cdots \cdots \cdots \\
f_{N}\left(x_{1}, x_{2}, \cdots, x_{N}\right)=\mu_{N}^{\beta}-\mu_{N}^{\alpha}=0
\end{gathered}
$$

と置く. (24)の 1 元高次方程式の場合と同様に考㝋て, ある近似值 $x_{1}^{(n)}, x_{2}^{(n)}, \cdots, x_{N}^{(n)}$ がそれぞれ $\varepsilon_{1}^{(n)}, \varepsilon_{2}^{(n)}, \cdots$, $\varepsilon_{N}^{(n)}$ の誤差とすると, 多変数に対する Taylor 展開をし $\tau$

$$
\begin{aligned}
& f_{i}\left(x_{1}^{(n)}+\varepsilon_{1}^{(n)}, \cdots, x_{N}^{(n)}+\varepsilon_{N}^{(n)}\right) \\
& =f_{i}\left(x_{1}^{(n)}, \cdots, x_{N}^{(n)}\right)+\sum_{k=1}^{N} \varepsilon_{k}^{(n)} \frac{\partial f_{i}}{\partial x_{k}} \\
& \quad+\cdots=0,(i=1,2, \cdots, \mathrm{N})
\end{aligned}
$$

2 次以上の項を無視すると

$$
\begin{aligned}
& \varepsilon_{1}^{(n)} \frac{\partial f_{1}}{\partial x_{1}}+\varepsilon_{2}^{(n)} \frac{\partial f_{1}}{\partial x_{2}}+\cdots+\varepsilon_{N}^{(n)} \frac{\partial f_{1}}{\partial x_{N}}=-f_{1} \\
& \cdots \cdots \cdots \\
& \varepsilon_{1}^{(n)} \frac{\partial f_{N}}{\partial x_{1}}+\varepsilon_{2}^{(n)} \frac{\partial f_{N}}{\partial x_{2}}+\cdots+\varepsilon_{N}^{(n)} \frac{\partial f_{N}}{\partial x_{N}}=-f_{N}
\end{aligned}
$$

と $\varepsilon_{i}^{(n)}$ に関する $N$ 元連立 1 次方程式となる. この方程 式の解 $\varepsilon_{i}^{(n)}$ は形式的には

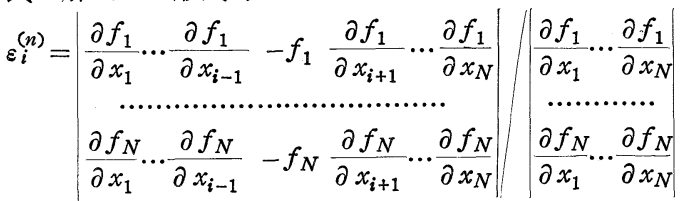

と書けるが，実際の計算はよく知られた消去法と呼ばれ る方法で計算する方が速い。(30) 式から求めた $\varepsilon_{i}^{(n)}$ を用 いて実際の計算は $x_{i}^{(n+1)}=x_{i}^{(n)}+\varepsilon_{i}^{(n)}$ として, 再び $(30)$ 式 から $\varepsilon_{i}^{(n+1)}$ を計算する. これを $\varepsilon_{i}^{(n)}$ が十分小さくなるま で繰返し, 解 $x_{1}, x_{2}, \cdots, x_{N}$ を求める. この方法は Hurle, Pike $^{(90)}$ や Kaufman, Bernstein ${ }^{(10)}$ らが状態図の計算に 用いたものである.

$N$ が大きい多元系のときには，一般にこの方法は複雑 になり（i)またはつぎに述べる（2）のよらな方法が簡 単であろう。 
その他の方法として(28)式を

$$
F=\sum_{i=1}^{N} f_{i}^{2}
$$

と置き，この $F$ の最小值を求める方法がある ${ }^{(9)(80)}$.この 最小值は $f_{i}=0$ のときであることは明らかである.

\section{（2）自由エネルギーの極小值を求める方法}

前節に打ける状態図の計算は, 相平衡の条件である (11)式を解く方法であった. この条件とは，言い換えれ ば系全体の自由エネルギーが最小であることに外ならな い. 再び第 3 図を見ると, 組成が $x_{1}$ のときには $\alpha$ 単相 で系の自由エネルギーは $G^{t}=G^{\alpha}\left(x_{1}\right)$ で最小であり, 組成 が $x_{2}$ のときには $\beta$ 単相で系の自由エネルギーは $G^{t}=G^{\beta}$ $\left(x_{2}\right)$ で最小である. 合金組成が $x_{3}$ のときは $\alpha$ または $\beta$ 単相であるよりも $x^{\alpha e}$ の $\alpha$ 相之 $x^{\beta e}$ の $\beta$ 相に分離し，采 全体として $G^{t}=G^{\alpha_{\beta}}$ となるのが最小である.

今 $i$ 成分の組成が $x_{i}^{\circ}(i=1,2, \cdots, N)$ である $N$ 元合金 を考光よう．この合金が $\alpha, \beta$ の 2 相に分解し，各相の組 成は $\left(x_{1}^{\alpha}, x_{2}^{\alpha}, \cdots, x_{N}^{\alpha}\right),\left(x_{1}^{\beta}, x_{2}^{\beta}, \cdots, x_{N}^{\beta}\right)$ であるとする。 のとき系全体の自由エネルギー $G^{t}$ は

$G^{t}=p G^{\alpha}\left(x_{1}^{\alpha}, x_{2}^{\alpha}, \cdots, x_{N}^{\alpha}\right)+(1-p) G^{\beta}\left(x_{1}^{\beta}, x_{2}^{\beta}, \cdots, x_{N}^{\beta}\right)(33)$ である。ここで $G^{\alpha}, G^{\beta}$ はそれぞれ $\alpha, \beta$ 相の $1 \mathrm{~g}$ 一原子あ たりの自由エネルギーで( 3 )式の形を持つ。また $p$ は $\alpha$ 相のモル分率を示し，これは各成分の組成と

$$
x_{i}^{\circ}=p x_{i}^{\alpha}+(1-p) x_{i}^{\beta}, \quad(i=1,2, \cdots, N)
$$

の関係がある。また $\sum x_{i}^{\alpha}=1, \Sigma x_{i}^{\beta}=1$ であるから, (33) 式は結局 $N$ 個の独立变数からなる関数となる. よってこ れを

$$
G^{t}=G^{t}\left(x_{1}, x_{2}, \cdots, x_{N}\right)
$$

とあらためて書き換える。 この(35)式の最小值は極值の 条件

$$
\frac{\partial G^{t}}{\partial x_{i}}=0,(i=1,2, \cdots, N)
$$

の $N$ 元連立方程式を解けばよい，Gaye，Lupis (77) はこ のような方法で 3 元系状態図の計算を行なっている. し かしこの(36)式を解くには前節で述べた方法などを用い なければならず，本質的には同じである。そこでここで は別な方法の最急降下法での計算について述べよう。

最急降下法にもいろいろな方法があるが，ここではそ のうちのもっとも簡単な方法を 2 元系の場合について説 明する。第 5 図は最急降下法の説明のための模式図で, $G^{t}=$ 一定の曲線を描いてある。計算はまずある近似値 $\left(x^{(0)}, y^{(0)}\right)$ を適当に選ぶ.つぎにこの点のまわり数点, たとえば $\left(x^{(0)}+\varepsilon, y^{(0)}\right),\left(x^{(0)}-\varepsilon, y^{(0)}\right),\left(x^{(0)}, y^{(0)}+\varepsilon\right)$, $\left(x^{(0)}, y^{(0)}-\varepsilon\right)$ などをとり，各点に拉ける $G^{t}$ を計算し, 点 $\left(x^{(0)}, y^{(0)}\right)$ よりも小さい点があれば，その点を第 2 の 近似解としてこれを繰返す。西る点 $\left(x^{(n)}, y^{(n)}\right)$ における

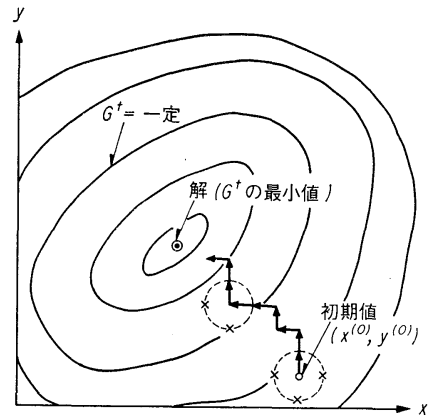

第 5 図 最急降下法による解法(近似值のまわり の数点を調べて今より低い所へ進む)

$G^{t}$ よりも小さい点がまわりになければををさらに小さ くして同様の探索を繰返し，所定の大きさの ときの $\left(x^{(n)}, y^{(n)}\right)$ を解とする。たと学ば Counsell, Lees， Spencer ${ }^{(109)(113)}$ はこの方法で状態㘠を計算している。

この方法は他の方法と比較して, 根への収束はあまり 速くない(4.(4)参照)。しかし Netwton-Raphson 法な ぞと違って微分計算の必要がないため $N$ の大きな多元 系の場合に適している。一般的な $N$ 元の場合の計算方法 については Powel1(42) や Nelder, Mead (43) の論文を参照 されたい。

\section{4． 状態図計算のプログラムの実例}

状態図計算のプログラムはすでに Rudman ${ }^{(9)}$ や Kaufman, Bernstein ${ }^{(10)}$ によって発表されている。しかし Rudman の方法は (32)式の最小值を探すのにすべての $x_{i}$ の組合わせを調べるという方法で非常に時間がかか り，多元系にすぐに応用できない，また Kaufman らの ものは Newton-Raphson 法によるものであるが, 単純な 正則溶体近似式のみにしか用いられない.

ここでは前章で説明した各方法を用いて，相互作用パ ラメータを

$$
\begin{aligned}
\Omega_{\mathrm{AB}} & =\left(B_{0}^{h}-T B_{0}^{s}\right)+\left(B_{1}^{h}-T B_{1}^{s}\right)\left(x_{\mathrm{B}}-x_{\mathrm{A}}\right) \\
& +\left(B_{2}^{h}-T B_{2}^{s}\right)\left(x_{\mathrm{B}}-x_{\mathrm{A}}\right)^{2}+\cdots+\left(B_{n}^{h}-T B_{n}^{s}\right)\left(x_{\mathrm{B}}-x_{\mathrm{A}}\right)^{n}
\end{aligned}
$$

のように温度の 1 次式, 組成の $n$ 次式 $(n \leq 5)$ で表わし た一般的な場合の 2 元系状態困の 2 相平衡を計算するプ ログラムの一例を紹介しょう。これらはいずれも JIS FORTRAN(水準 7000)飞従ってプログラミングした.

\section{(1) Gauss-Seidel 法(BZERO その 1)}

Gauss-Seidel 法によるプログラムを第 1 表に示した. $\mathrm{A}, \mathrm{B}$ はそれぞれ $\alpha, \beta$ 相の相互作用パラメータを表わす

(42) M.J.D.Powell : Computer J., 7(1964/5), 155, 303.

(43) J.A.Nelder and R.Mead : Computer J., 7 (1964/ 5), 308 . 
各値で（6)式中のパラメータ $B_{n} を R T$ で割ったもの に相当する。 またXは $\alpha$ 相の, $\mathrm{Y} は \beta$ 相の第 2 成分の組 成で，ここの例では $\mathrm{X}<\mathrm{Y}$ を仮定している, G1, G 2 は それぞれ第 1 , 第 2 成分の自由エネルギー差 $\left({ }^{\circ} G_{i}^{\alpha}-{ }^{\circ} G_{i}^{\beta}\right)$ を表わす、XOLD, TYOLD は反復演算前の近似值であ り, 反復後の值 $\mathrm{X}, \mathrm{TY}$ との差が両方とも $1 . \mathrm{E}-5\left(1 \times 10^{-5}\right.$ の意味) 以下ならば反復を打ち切り，そのときの $\mathrm{X}, \mathrm{Y}$ を 解とする.

$\mathrm{OM}(\mathrm{A}, \mathrm{X}, \mathrm{K})$ は FUNCTION サブプログラムで, 第2 表に示した。 これは相互作用パラメータとその導関数を 計算するためのプログラムで, Kは導関数の次数を表わ す. またこの相互作用パラメータは 5 次以内の近似式に 用いることができる。これは組成依存性を(6)式の形で 表わした場合のものであるが，（5)式の形で用いる場合 でも組成の項を少し変えるだけで使用できる.

\section{(2) Newton-Raphson 法(BZERO その 2 )}

Newton-Raphson 法によるプログラムを第3 表に示し た. A, B, X, Y, G1, G 2 抽よび FUNCTION OM は(1) Gauss-Seidel 法の場合と同じである，F1，F２はとれ亮 れ

$$
\begin{aligned}
& f_{1}=\mu_{1}^{\alpha}-\mu_{1}^{\beta}=0 \\
& f_{2}=\mu_{2}^{\alpha}-\mu_{2}^{\beta}=0
\end{aligned}
$$

を表わし, DX 1, DX 2, DY 1, DY 2 はそれぞれ $\partial \mathrm{F} 1 /$ $\partial \mathrm{X}, \partial \mathrm{F} 2 / \partial \mathrm{X}, \partial \mathrm{F} 1 / \partial \mathrm{Y}, \partial \mathrm{F} 2 / \partial \mathrm{Y}$ である.

ある近似值 $\mathrm{X}, \mathrm{Y}$ から $\mathrm{DX}, \mathrm{DY}$ を計算し, $\mathrm{X}+\mathrm{DX}$, $\mathrm{Y}+\mathrm{DY}$ をつぎの近似值とする。これを繰返し DX, DY の絶対値がともに $1 \times 10^{-5}$ 以下になったとき計算を打ち 切り，そのときの X, Y を解とする。

\section{(3) 最急降下法(BGMIN)}

自由エネルギー極小化に対する最急降下法のプログラ ムを第 4 表に揭げる. A, B, X, Y, G 1, G 2, FUNCTION OM は(1)Gauss-Seidel 法の場合と同じで，Zは合金の 全組成で(34)式中の $x^{\circ}$ に相当する. またFUNCTION $\mathrm{GF}$ は 2 元系固溶体の自由エネルギーを計算するサブプ ログラムである.

ある近似值 $(\mathrm{X}, \mathrm{Y})$ のまわり $(\mathrm{X}+\mathrm{EPS}, \mathrm{Y}),(\mathrm{X}-\mathrm{EPS}, \mathrm{Y})$, $(\mathrm{X}, \mathrm{Y}+\mathrm{EPS}),(\mathrm{X}, \mathrm{Y}-\mathrm{EPS})$ の 4 点における全自由エネル ギー GM を計算し，(X,Y)に打ける自由エネルギー GMIN と比較する。このプログラムではひとたび小さい 方向が見つかれば，その方向が上りになるまで進む。 ま わりがすべて大きければ EPS $\times 0.1$ を新たに EPS とし， これを繰返す。この EPSが $1 \times 10^{-5}$ よりも小さくなっ たら計算を打ち切り，そのときの X, Yを解とする。

\section{(4) 主プログラムと計算例}

以上三つの方法による 2 相平衡計算のためのプログラ
ムをSUBROUTINE として示したが,これらを用いたも っとも簡単な例として $\mathrm{Au}-\mathrm{Ni} 2$ 元系の 2 相分離線を計 算してみよう。

この 2 元系の熱力学的性質については多くの研究があ $\eta^{(44)}, \Omega_{\mathrm{AuNi}}$ の值はつぎのように表わされる.

$$
\begin{aligned}
\Omega_{\mathrm{AuNi}}= & (7059-2.875 T)+(2233-0.918 T)\left(x_{\mathrm{Ni}}-x_{\mathrm{Au}}\right) \\
& +(-585+1.246 T)\left(x_{\mathrm{Ni}}-x_{\mathrm{Au}}\right)^{2} \\
& +(-2574+2.441 T)\left(x_{\mathrm{Ni}}-x_{\mathrm{Au}}\right)^{3}
\end{aligned}
$$

どの SUBROUTINEを用いる場合にもあらかじめ初 期值を探さなければならない。ここではこのためにスピ ノーダル点を計算する.

第 5 表はスピノーダル点を計算するためのプログラム SUBROUTINE BISPN とSUBROUTINE SPNODB であ る.このプログラム中の G $2, \mathrm{G} 3, \mathrm{G} 4$ は自由エネルギ 一関数の 2 次, 3 次, 4 次導関数である.

スピノーダル点の計算は比較的容易で $\partial^{2} G / \partial x^{2}=0 つ$ まり $\mathrm{G} 2=0$ の点を求めることである. 第 6 図を見てい ただこう。これは $\mathrm{Au}-\mathrm{Ni}$ 系の $700^{\circ} \mathrm{C}$ における $G, \partial G /$ $\partial x, \partial^{2} G / \partial x^{2}$ を描いたものである. $\partial^{2} G / \partial x^{2}$ の曲線はど んな系でも注涪同じ形をとる。計算はまずスピノーダル 点が存在するかどうかを判定するために, G $3=0$ の点つ まり G 2 の極小点 (XMIN)を求める. この XMIN にお ける G 2 の值が正のときは $\mathrm{G} 2=0$ の点つまりスピノー

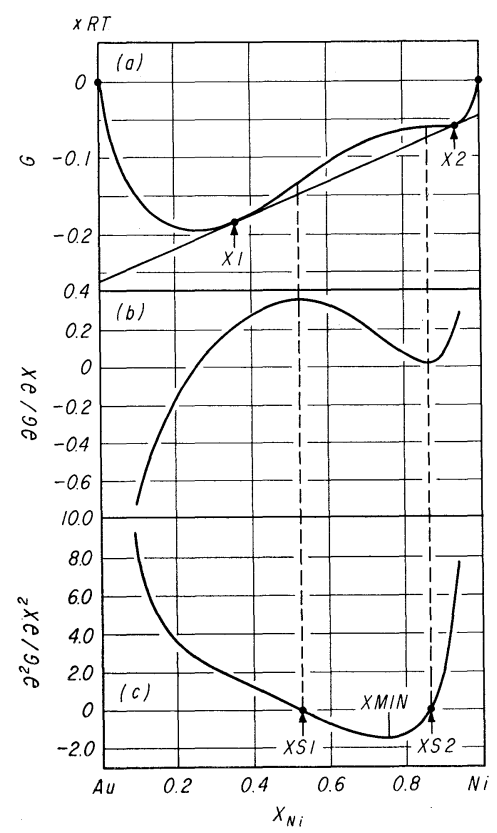

第6因 $700^{\circ} \mathrm{C}$ に打ける $\mathrm{Au}-\mathrm{Ni}$ 系の (a) 自由エネルギーー組成図, (b) (a)の 1 次微分, (c) (a)の 2 次微分

(44) R.Hultgren, R.L.Orr, P.D.Anderson and K.K. Kelley : Selected Values of Thermodynamic Properties of Metals and Alloys, J.Wiley and Sons, N.Y., (1963) . 
ダル点は存在せず，したがって 2 相分離も起きない. XMIN において G 2 が負のときにはスピノーダル点があ り $\mathrm{XMIN} \times 0.25$ と $(\mathrm{XMIN}+3) \times 0.25$ を近似值として SUBROUTINE SPNODB でスピノーダル点を計算する. XMIN およびスピノーダル点の計算は 1 元高次方程式 の場合の Newton-Raphson 法で行なう.

こうして求めたスピノーダル点 XS $1, \mathrm{XS} 2$ から, XS 1/3. , (XS 2+2.)/3. を初期値として用いる.

第 6 表は 2 相分離線を計算するための主プログラムで ある。ここで ELEM は構成元素名で $\operatorname{ELEM}(1)$ は第 1 成分, $\operatorname{ELEM}(2)$ は第 2 成分を表わし, AH, AS はそれ ぞれ(36)式中の $B_{n}^{h}, B_{n}^{s}$ に相当する. また計算は温度 TL から TH まで DT 間隔で行なうものとする。なお,この 温度は ${ }^{\circ} \mathrm{C}$ で入力する。 ステートメント 21 で SUBROUTINE BGMIN をCALL するときは, この前に $Z=$ (XS 1+XS 2)/2．とする.

この主プログラムを用いて $700^{\circ} \mathrm{C}$ における Au-Ni 2 元系の 2 相分離線を上記の三方法で計算した途中経過を 第7〜9表に掲げた。表中の DX 1, DX 2 は前近似値と 新近似值との差を示している。これらの表からわかるよ らに三つの方法のらちでは Newton-Raphson 法がもっ とも反復回数が少ない. 最後の桁が少し違うのは近似法 の違いによる誤差である.

Newton-Raphson 法で計算した最終結果を第 10 表に 示した。 また第7 図はこうして計算した $\mathrm{Au}-\mathrm{Ni}$ 系の状 態罒である.

なおこの主プログラムは DTを大きくとっていること を仮定している，DT が小さい，たとえば $1^{\circ} \mathrm{C}$ のきに

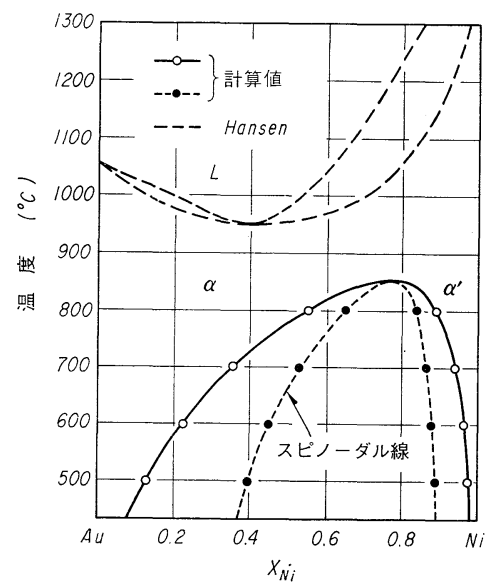

第7困 Au-Ni 2 元系状態図

(45) R.Hultgren, R.L.Orr and K.K.Kelley : Supplement to Selected Values of Thermodynamic Properties of Metals and Alloys, Univ. of California, (1965-69).

(46) M. Hansen and K. Anderko : Constitution of Binary Alloys, McGraw-Hill, (1958).
はそのたびに BISPN でスピノーダル点を計算するのは 得策でなく, 前回の 2 相分離点を近似值として用いる方 がよい.

\section{5.コンピュータによる状態図の構成}

前記の例からも知られるように熱力学データから状態 図が計算でき, 逆に状態図から熱力学データを抽出する ことができる．したがって両者の間には密接な関係があ るわけである. しかし現在「Selected Values of Thermodynamic Properties of Metals and Alloys 」(44)(45) と「Constitution of Binary Alloys」(46) (48) に代表され るように, 状態図と熱力学データは別々に集録されてい るのが普通である、コンピュータの利用を考えれば，こ れら二つのものは同じ形で貯えられ同じ過程で処理すべ きであろら。

第 8 図は最近行なわれつつある状態図研究のフローチ ャートである. 入力情報としては活量, 熱量, エントロ ピー, 比熱などの熱力学的実験值 $(\mathrm{A})$ と顕微鏡組織観察, マイクロアナライザー分析，X線回折，熱分析などの金 属組織学的実験値(B)がある．従来の状態図はほとんど

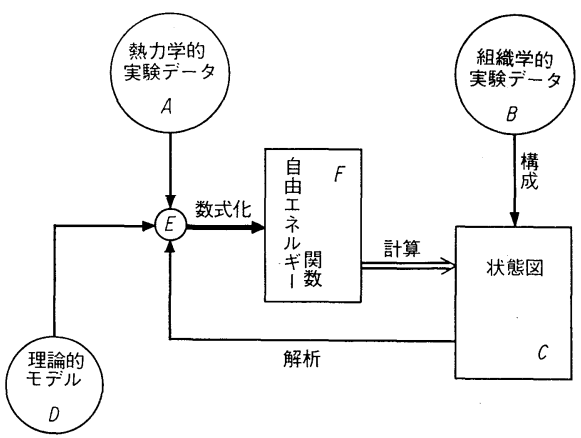

第 8 図 新しい状態図の構成法

が Bのデータに基づいて構成されたものである(46) (48). 先に述べた Meijering らの方法はAのデータを理論的な

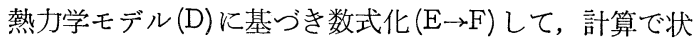
態図 (C)を構成するものである. Borelius らはこれと逆 に熱力学的データのない系に対して実験的に構成された 状態図を熱力学的に解析し $(\mathrm{C} \rightarrow \mathrm{E})$, その系の熱力学的性 質を求めた。今まではこれらがほとんど独立して用いら れていたに過ざなかったが，状態図を解析して得た值は 熱力学的研究で直接得られる值と比較検討し $(\mathrm{E})$, より 正確な熱力学関数 $(F)$ をそしてこれからより正確な状 態図が構成されるべきである(9)(128).

こうして状態図に熱力学を用い, 両者が関係つけられ

(47) R.P.Elliott : Constitution of Binary Alloys, Supplement, McGraw-Hill, (1965).

(48) F.A.Shunk : Constitution of Binary Alloys, 2 nd Supplement, McGraw-Hill, (1969). 
第 1 表 Gauss-Seidel 法によるプログラム(BZERO その 1$)$

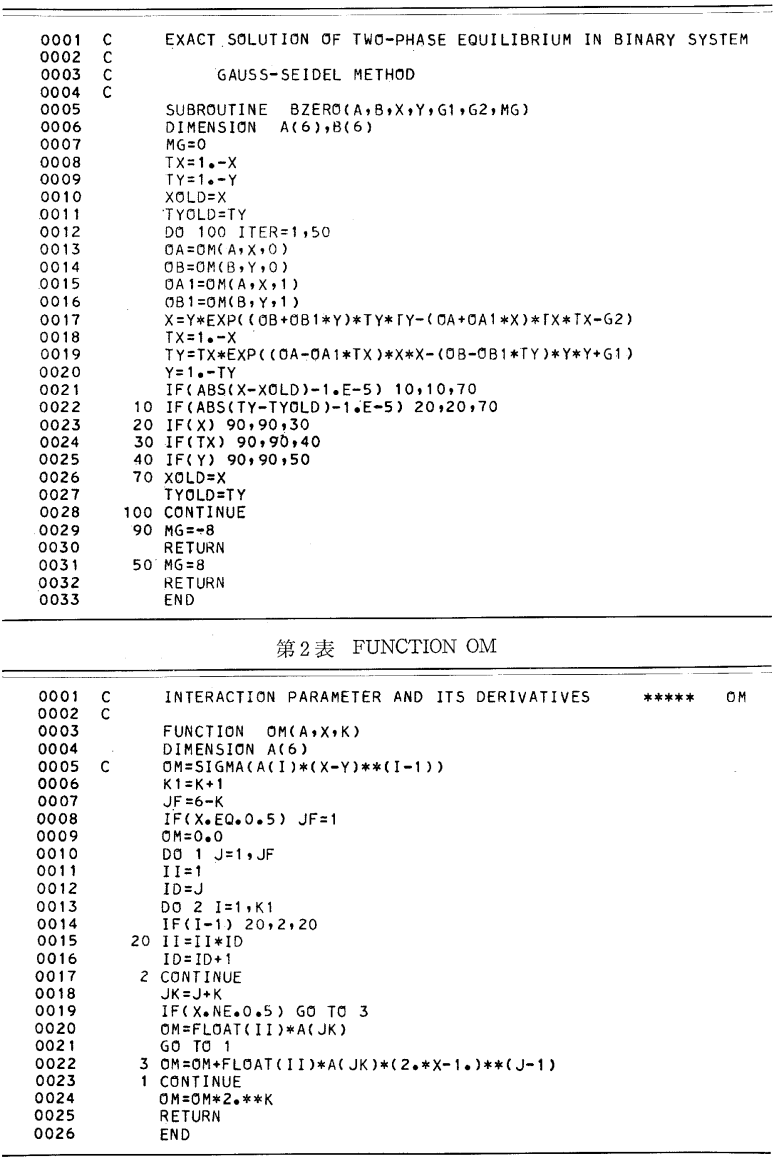

第3表 Newton-Raphson 法によるプログラム(BZERO その 2)

\begin{tabular}{|c|c|c|}
\hline $\begin{array}{l}0001 \\
0002 \\
0003\end{array}$ & $\begin{array}{l}c \\
c \\
c\end{array}$ & $\begin{array}{l}\text { EXACT SOLUTION OF TWO-PHASE EOUILIBRIUM IN BINARY SYSTEM } \\
* * * * * \text { BZERO } \\
\text { NEWTON-RAPHSON METHOD }\end{array}$ \\
\hline 0004 & & \\
\hline 0005 & & SUBROUTINE BZERO $(A, B, X, Y, G 1, G 2, M G)$ \\
\hline $\begin{array}{l}0006 \\
0007\end{array}$ & & $\begin{array}{l}\text { DIMENSION } A(6), B(6) \\
M G=0\end{array}$ \\
\hline & & $T X=1 .-X$ \\
\hline 0009 & & $T Y=1,-Y{ }^{2}$ \\
\hline 0010 & & DO 100 ITER $=1,50$ \\
\hline 0011 & & $O A=O M(A, X, O)$ \\
\hline 0012 & & $O B=O M(B, Y, O)$ \\
\hline 0013 & & $O A 1=O M(A, X, 1)$ \\
\hline 0014 & & $O B 1=O M(B, Y, 1)$ \\
\hline 0015 & & $O A 2=O M(A, X, 2)$ \\
\hline 0016 & & $O B 2=O M(B, Y, 2)$ \\
\hline 0017 & & $F 1=G 1+A L O G(T X / T Y)+(O A-O A 1 * T X) * X * X-(O B-O B 1 * T Y) * Y * Y$ \\
\hline 0018 & & $F 2=G 2+A L O G(X / Y)+(O A+O A 1 * X) * T X * T X-(O B+O B 1 * Y) * T Y * T Y$ \\
\hline 0019 & & $A X=2 . *(O A+O A 1 *(X-T X))-O A 2 * X * T X$ \\
\hline 0020 & & $\begin{array}{l}A X=2 . *(O B+O B 1 *(Y-T Y))-O B 2 * Y * T Y \\
B Y=2(Y)\end{array}$ \\
\hline 0021 & & $D X 1=A X * X-1 . / T X$ \\
\hline 0022 & & $D X 2=-A X * T X+1.1 X$ \\
\hline 0023 & & $D Y 1=-B Y * Y+1 . / T Y$ \\
\hline 0024 & & $D Y 2=B Y * T Y-1 . / Y$ \\
\hline 0025 & & $F X=D X 1 * D Y 2-D Y 1 * D X 2$ \\
\hline 0026 & & $D X=(F 2 * D Y 1-F 1 * D Y 2) / F X$ \\
\hline 0027 & & $D Y=(F 1 * D \times 2-F 2 * D X 1) / F \hat{X}$ \\
\hline 0028 & & $x=x+D x$ \\
\hline 0029 & & $\hat{Y}=\hat{Y}+D \hat{Y}$ \\
\hline 0030 & & $T X=1 .-x$ \\
\hline 0031 & & $T Y=1 .-Y$ \\
\hline 0032 & & $\operatorname{IF}(A B S(D X)+.00001) 10,10,70$ \\
\hline 0033 & 10 & IF(ABS(DY)-.00001) $20,20,70$ \\
\hline 0034 & 20 & $\operatorname{IF}(x) 90,90,30$ \\
\hline 0035 & 30 & $I F(T X) 90,90,40$ \\
\hline 0036 & 40 & IF (Y) $90,90,50$ \\
\hline 0037 & 50 & IF (TY) $90,90,60$ \\
\hline 0038 & 70 & IF $(X) 80,80,15$ \\
\hline 0039 & 15 & $\operatorname{IF}(\mathrm{TX}) 80,80,25$ \\
\hline 0040 & 80 & $\mathrm{DX}=\mathrm{DX} / 2$. \\
\hline 0041 & & $x=x-D x$ \\
\hline 0042 & & GO TO 70 \\
\hline & 25 & IF(Y) $35,35,75$ \\
\hline 0044 & 75 & IF (TY) $35,35,100$ \\
\hline 0045 & 35 & $D Y=D Y / 2$ \\
\hline 0046 & & $Y=Y=D Y$ \\
\hline 0047 & & GO TO 25 \\
\hline 0048 & 100 & CONTINUE \\
\hline 0049 & 90 & $M G=-8$ \\
\hline 0050 & & RETURN \\
\hline 0051 & 60 & $M G=8$ \\
\hline 0052 & & RETURN \\
\hline 0053 & & \\
\hline
\end{tabular}

第 4 表 最急降下法によるブログラム (BGMIN)

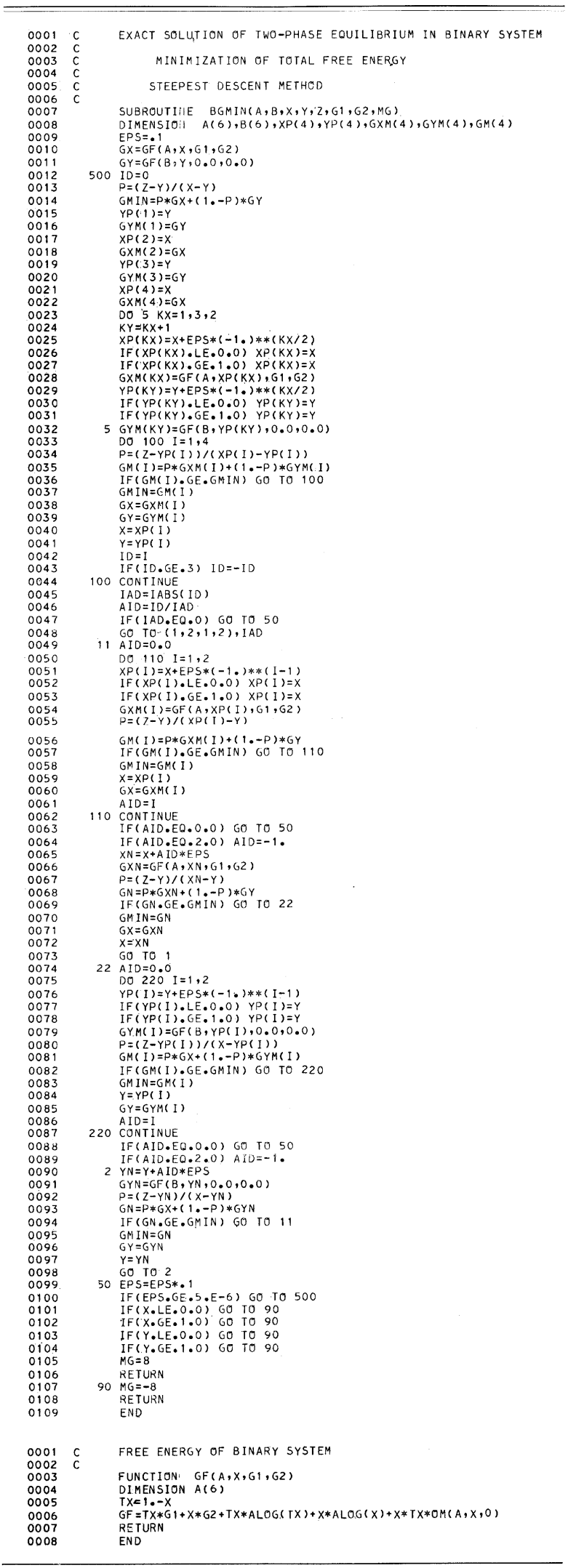


第 5 表 SUBROUTINE BISPN と SPNODB

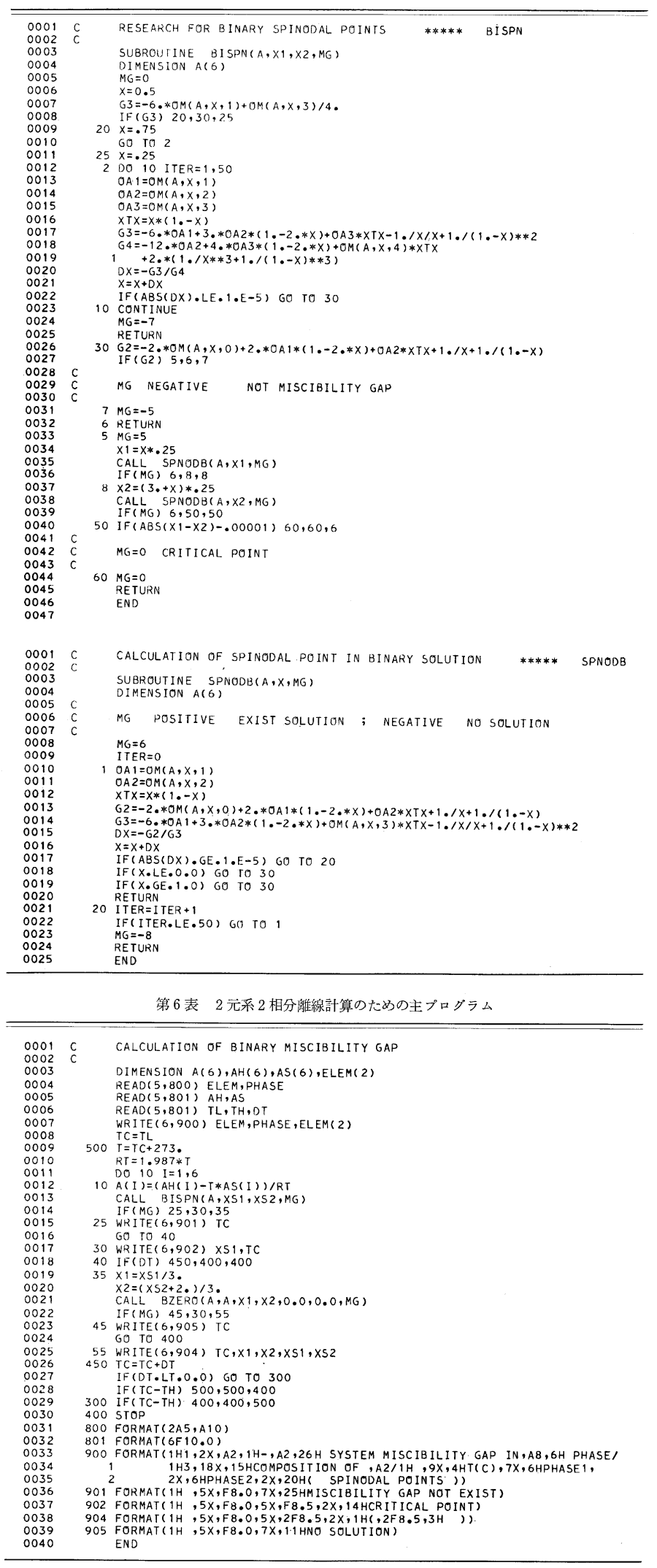

第 7 表 Gauss-Seidel 法(BZERO その 1)による 計算経過 $\left(700^{\circ} \mathrm{C}\right)$

\begin{tabular}{|c|c|c|c|c|}
\hline 1 & $\times 1$ & $D \times 1$ & $\times 2$ & $D \times 2$ \\
\hline 1 & .17508 & & .93463 & \\
\hline 2 & $.2526 \equiv$ & . $77 \equiv 71 \mathrm{E}-01$ & .94240 & $-.12232 E-01$ \\
\hline 3 & .29594 & $.43289 \mathrm{E}-01$ & .93771 & $-.46869 \mathrm{E}-02$ \\
\hline 4 & .32030 & $.24358 \mathrm{E}-01$ & .93624 & $\begin{array}{r}-.14690 E-02 \\
-1460\end{array}$ \\
\hline 5 & .33452 & $.14218 E-01$ & .93607 & $-.16692 \mathrm{E}-03$ \\
\hline 6 & .34311 & $.85928 \mathrm{E}-02$ & .93637 & $.29343 E-C 3$ \\
\hline$?$ & .34845 & $.53388 \mathrm{E}-02$ & .93676 & $.39856 \mathrm{E}-03$ \\
\hline & .35184 & . $33881 \mathrm{E}-02$ & .93713 & . $36775 \mathrm{E}-\mathrm{C3}$ \\
\hline & .35402 & $.21847 \mathrm{E}-02$ & .93743 & $.2966 \equiv E-03$ \\
\hline 10 & . 35545 & $.14255 \mathrm{E}-02$ & .93765 & $.22390 E-03$ \\
\hline 11 & .35638 & $.93822 \mathrm{E}-03$ & .93782 & $.162660-03$ \\
\hline 12 & .35701 & $.02146 \mathrm{E}-03$ & $\begin{array}{l}.93793 \\
.93793\end{array}$ & $.11539 E-C 3$ \\
\hline 13 & .35742 & $.41355 \mathrm{E}-03$ & .93801 & $.80601 \mathrm{E}-04$ \\
\hline 14 & .35770 & $.27612 \mathrm{E}-03$ & .93807 & - 55712E-C4 \\
\hline $1 \equiv$ & .35788 & $.18481 \mathrm{E}-03$ & .93811 & $.38232 \mathrm{E}-04$ \\
\hline 16 & .35800 & $.12391 \mathrm{E}-03$ & .93813 & $.26104 E-04$ \\
\hline 17 & .35809 & $.83181 \mathrm{E}-04$ & .93815 & $.177 \equiv 9 E-04$ \\
\hline 18 & .35814 & $.55892 \mathrm{E}-\mathrm{CH}$ & .93816 & $.120 \equiv 0 E-04$ \\
\hline 19 & .35818 & $.37581 \mathrm{E}-04$ & .93817 & $.81615 E-05$ \\
\hline & .35821 & $.25282 \mathrm{E}-04$ & .93817 & $.55201 \mathrm{E}-05$ \\
\hline & .35822 & $.17014 \mathrm{E}-04$ & .93818 & $.37298 \mathrm{E}-0 \mathrm{E}$ \\
\hline 22 & .35823 & $.11453 E-04$ & .93818 & $.25183 E-05$ \\
\hline 23 & .35824 & $.77108 \mathrm{E}-05$ & .93818 & $.16993 E-05$ \\
\hline & 第 8 表 & \multicolumn{3}{|c|}{$\begin{array}{l}\text { Newton-Raphson 法(BZERO その } 2) \\
\text { による計算経過 }\left(700^{\circ} \mathrm{C}\right)\end{array}$} \\
\hline I & $x 1$ & $D \times 1$ & $\times 2$ & $D \times 2$ \\
\hline 1 & .17508 & & .95463 & \\
\hline 2 & .28173 & $.10665 E+C 0$ & .93855 & $-16075 \mathrm{E}-01$ \\
\hline 3 & .34197 & $.60236 E-01$ & .93714 & $-.14121 \mathrm{E}-02$ \\
\hline 4 & .35732 & $.15355 \mathrm{E}-01$ & .93816 & $.10163 E-02$ \\
\hline 5 & . 35825 & $.93359 E-03$ & .93819 & $.30196 \mathrm{E}-04$ \\
\hline 6 & .35826 & $.33697 \mathrm{E}-05$ & .93819 & $.14045 \mathrm{E}-06$ \\
\hline
\end{tabular}

第 9 表 最急降下法(BGMIN)による 計算経過 $\left(700^{\circ} \mathrm{C}\right)$

\begin{tabular}{|c|c|c|c|}
\hline I & $x_{1}$ & $y_{2}$ & EPS \\
\hline 1 & .17508 & .95463 & .100000 \\
\hline 2 & .27508 & & \\
\hline 3 & .37508 & & \\
\hline $\begin{array}{l}4 \\
5\end{array}$ & .37508 & $\begin{array}{r}95463 \\
994463\end{array}$ & .010000 \\
\hline $\begin{array}{l}2 \\
6\end{array}$ & & .93463 & \\
\hline 7 & $\begin{array}{r}.36508 \\
\end{array}$ & & \\
\hline 8 & $\begin{array}{r}35508 \\
-35=08\end{array}$ & & \\
\hline 9 & $\cdot 35 \equiv 08$ & $\begin{array}{r}93463 \\
93=63\end{array}$ & .001000 \\
\hline $\begin{array}{l}16 \\
11\end{array}$ & & .93663 & \\
\hline 12 & & .93763 & \\
\hline 13 & & .93863 & \\
\hline 14 & .35608 & & \\
\hline 15 & .35708 & & \\
\hline 16 & $\cdot 3 \equiv 808$ & & \\
\hline 17 & $\cdot 35808$ & .93863 & .000100 \\
\hline 18 & & .93853 & \\
\hline 19 & & .93843 & \\
\hline 20 & & .93833 & \\
\hline 21 & & .93823 & \\
\hline 22 & $\cdot 35818$ & & \\
\hline 23 & $\begin{array}{r}35828 \\
35828\end{array}$ & & \\
\hline 24 & $\cdot 35828$ & $\begin{array}{r}93823 \\
0\end{array}$ & $\cdot 0.00010$ \\
\hline $\begin{array}{l}25 \\
26\end{array}$ & & $\begin{array}{r}93822 \\
.93821\end{array}$ & \\
\hline 27 & & .93820 & \\
\hline 28 & & .93819 & \\
\hline 29 & .35827 & & \\
\hline 30 & .35826 & & \\
\hline
\end{tabular}

第 10 表 $\mathrm{Au}-\mathrm{Ni} 2$ 元系 2 相分離線の計算結果

AM-NI SYSTEM MISCIBILITY EAP IN FCC PHASE

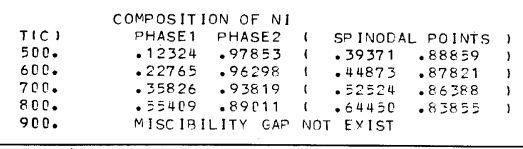


ると多くの利点がある．自由エネルギーを温度や組成の 関数として表わすことにより，はじめに述べたように， 全く実験データが得られていないか，または不確かな領 域，準安定領域にまで外插，内插し状態図の計算が行な える. このことは多元系状態㘠を構成する上でも非常に 有効で, $N$ 元系の場合に未知のパラメータが $M$ 個なら ば最低 $M / N$ 個の測定值(共役線)があればこのパラメー タを決められ, さらに全域にわたる相平衡が計算でき る.このように今まで非常に時間や労力を要した多元系 状態図の研究も熱力学とコンピェータを用いて容易にな る.さらに多元系では状態図をどのよらに平面上に描く か問題であったが, 自由エネルギー関数がわかっている ならば必要に応じてその部分を計算すればよい。

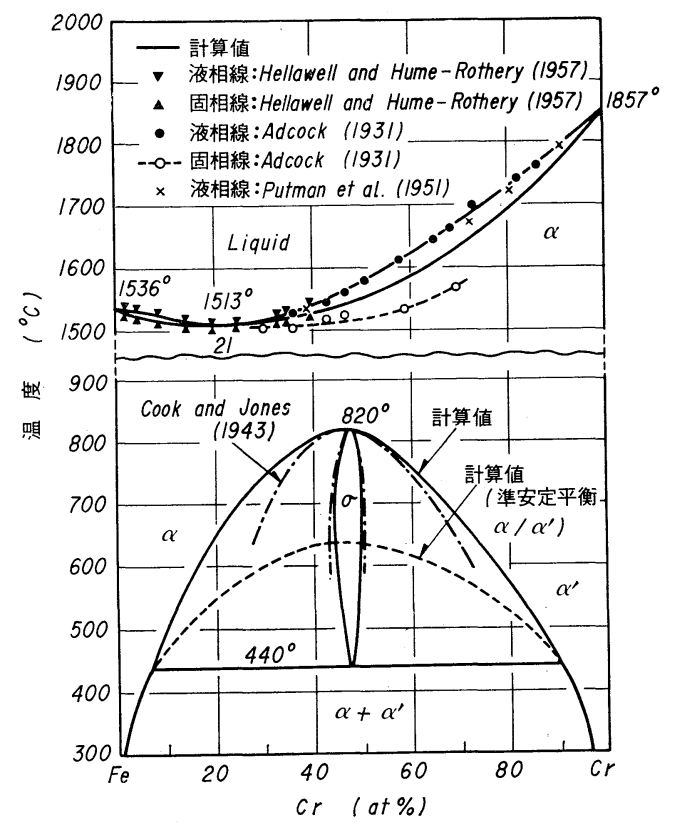

第 9 図 $\mathrm{Fe}-\mathrm{Cr} 2$ 元系状態図 ${ }^{(71)}$

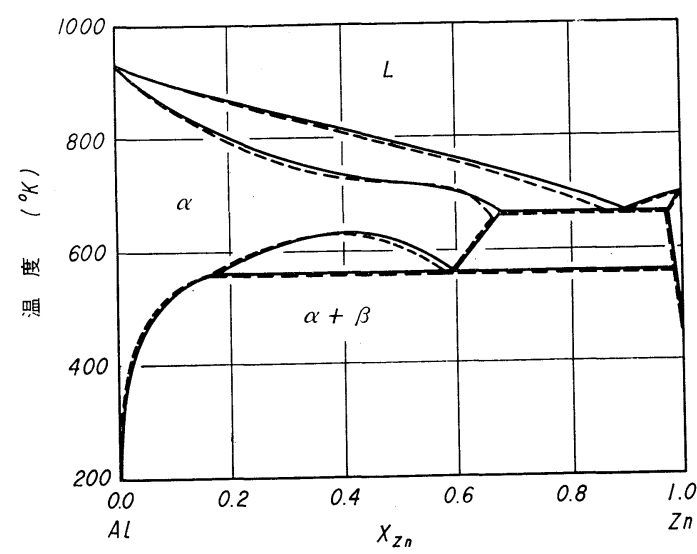

第 10 図 A1-Zn 2 元系状態図 ${ }^{(77)}$ (一計算值, ----実測值)
こうして実際に計算された状態図の例として第9図 ${ }^{(71)}$, 第 10 図 ${ }^{(77)}$ に $\mathrm{Fe}-\mathrm{Cr}, \mathrm{A} 1-\mathrm{Zn} 2$ 元系, 第 11 図 $^{(126)(127)}$ に $\mathrm{Fe}-\mathrm{C}-\mathrm{Cr} 3$ 元系の状態図を示す.

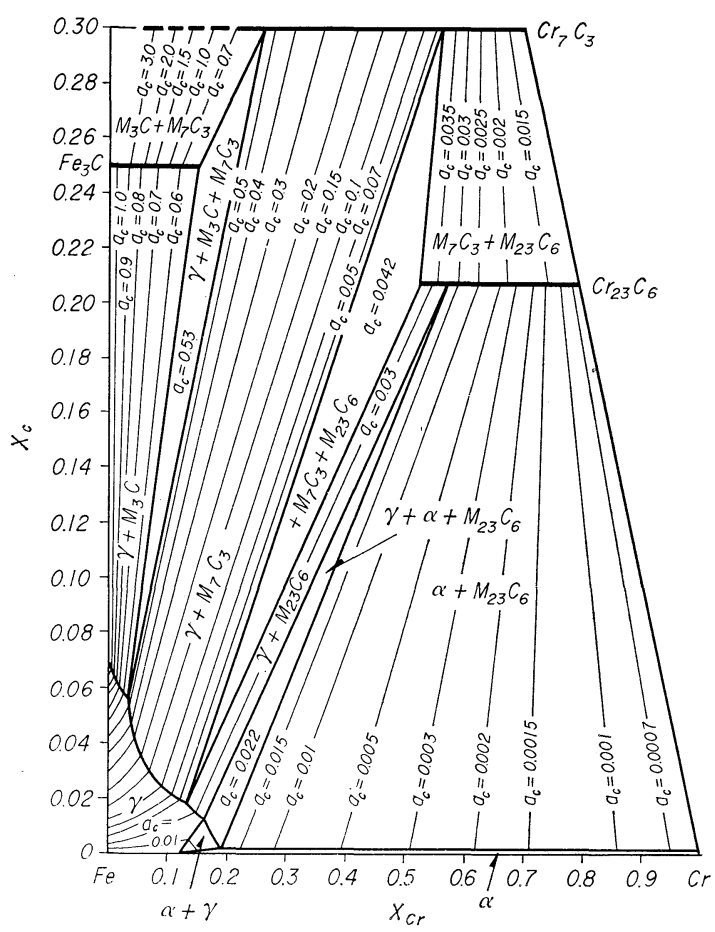

第11図 Fe-C-Cr 3 元系に打子る炭素の 等活量線闵 $\left(1000^{\circ} \mathrm{C}\right)(126)(127)$

\section{6. おわりに}

以上のように我々は自由エネルギー関数を知ることが できるとどんな相平衡でも直接コンピュータを用いて計 算でき，またコンピュータ付属のドラフターを利用して 状態図を描かせることもできる。このよらな計算は相変 態の研究に打いても理論と実験を比較する上で大切なこ とである。しかしながらすべての状態図を計算によって 構成することは 2 元系に拈いてすらまだ不可能である.

しかし，この目的に向って現在多くの研究が進めら れており, 特にスウェーデンの Hillert, イギリスの Kubaschewski, 米国の Lupis らのグループが積極的で ある、また特に注目すべきものに Kaufman(10) (66) (68) (69) の研究がある。これは全く純成分の熱力学データのみか

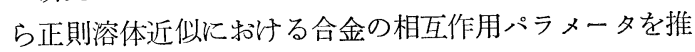
定し， 2 元系と 3 元系の状態図を計算しようとするもの で, データの全く存在しない合金系，たとえば高融点合 金の状態図の解析に多くの成果を上げている.

本稿では状態困をコンピュータ計算する場合の入門的 な事項を記述するにとどまり，その成果の紹介を割愛し たので興味のある方への参考資料としてできるだけ多く 
の文献を分類して末尾に示した ${ }^{(49) \sim(132)}$.

なお計算は東北大学大型計算機センターの NEAC シ リーズ $2200 \mathrm{MOD}$ VII にて行なった.

最後にプログラム作製にあたりご協力をいただいた東 北大学大学院高坂洋司氏に感謝します.

(1972 年 7 月 7 日受理)

〈参考文献 $>$

置換型 2 元合金

(49) F.J.Dunkerley and G.J.Mills: Thermodynamics in Physical Metallurgy, ASM, (1950), 57.

(50) C.D.Thurmond : J.Phys.Chem., 57(1953) , 827.

(51) C.D.Thurmond and J.Struthers: J.Phys.Chem., $57(1953), 831$

(52) C.Wagner : Acta Met., 2(1954), 242.

(53) W.F.Schottkey and M.B.Bever : Acta Met., 6 (1958), 320.

(54) L.Kaufman and A.E. Ringwood : Acta Met., 9 (1961) , 941.

(55) O.Kubaschewski : Thermodynamics of Nuclear Materials, IAEA, Vienna, (1962), 219.

(56) L.Kaufman : Solid under Pressure, Ed.by W. Paul and D.Warshauer, (1963), 303.

(57) M.Hillert : Metallic Solid Solution, Ed. by J. Friedel and A.Guinier, Benjamin, New York, (1963), pXLV II-8.

(58) S. V. Radcliffe and M. Schatz : Nature, 200 (1963) , 161.

(59) M.Schatz and L.Kaufman : Trans. Met. Soc. AIME, 230 (1964), 1564.

(60) ref. (8)

(61) R.E.Hanneman, R.E.Ogilvie and H.C.Gatos : Trans.Met.Soc.AIME, 233 (1965) , 685.

(62) L.Kaufman : Physical Metallurgy of Martensite and Bainite, B.I.S.R.A.and Institute of Metals, Report No.93, London, (1965), 48.

(63) H.Hoshino, Y.Nakamura, M.Shimoji and K. Niwa : Ber. Bunsenges. Phys. Chem., 69(1965), 114.

(64) M.Hillert, T.Wada and H.Wada : J.Iron Steel Inst., 205 (1967) , 539.

(65) O.Kubaschewski : Phase Stability in Metals and Alloys, Ed. by P.S. Rudman, J.Stringer and R.I.Jaffee, McGraw-Hill, New York, (1967), 63.

(66) L.Kaufman : ibid, 125.

(67) L.Kaufman : Energetics in Metallurgical Phenomena, Ed.by W.Mueller, Vol.3, Gordon and Breach, New York, (1967), 53.

(68) L.Kaufman: Prog.in Mater.Sci., Vol.13, (1969), 55 .

(69) L.Kaufman : The Science, Technology and Application of Titanium, Ed. by R.I.Jaffee and N.Promisel, Pergamon Press, New York, (1969), 347.

(70) ref. (9) and (128).

(71) F.Müller and O.Kubaschewski : High Temp.High Press., 1 (1969), 543.

(72) L.Elford,F.Müller and O.Kubaschewski : Ber. Bunsenges.Phys.Chem., 73(1969), 601.

(73) F.H.Hayes, F.Müller and O.Kubaschewski : J.Inst.Metals, 98(1970), 20.

(74) G.Pascoe and J.Mackowiak : J.Inst.Metals, 98 (1970) , 253.

(75) P.J.Spencer and W.Slough : High Temp.-High Press., 2(1970), 123.
(76) A.S.Jordan : Met.Trans., 1 (1970), 239.

(77) H.Gaye and C.H.P. Lupis : Scripta Met., 4 $(1970), 685$.

(78) J.Steininger : J.Appl.Phys., 41 (1970) , 2713.

(79) ref. (10)

(80) B.Gale and J.M.Davis : Metal Sci.J., 5(1971), 25.

(81) H.Harvig, G.Kirchner and M.Hillert : Met. Trans., 3 (1972) , 329.

(82) J.F.Breedis and L.Kaufman : Met.Trans., 2 (1971), 2359.

(83) D.Chatterji : Met.Trans., 2(1971), 2939.

(84) L.Kaufman : International Symposium on Metallurgical Chemistry, England, (1971) .

(85) G.Kirchner, H.Harvig, K.R.Moquist and M. Hillert : Die Verteilung von Zink Zwischen Ferrit und Austenit und die Thermodynamik des Zweistoffsystems Eisen-Zink, to be appeared in Arch. Eisenhütten.

(86) G.Kirchner, T. Nishizawa and B. Uhrenius : The Distribution of Chromium between Ferrite and Austenite and the thermodynamics of the $\alpha / \gamma$ Equilibrium in the Fe-Cr and Fe-Mn Systems, to be published.

(86-1) M. V. Rao and W.A.Tiller : J.Mater. Sci., 7 (1972), 14.

\section{置換型 3 元合金}

(87) ref. (5)

(88) K.Lehovec and A.Slobodskoy : J.Electrochem. Soc., $111(1964), 65$.

(89) Y.Furukawa and C.D. Thurmond : J.Phys. Chem. Solids, 26 (1965) , 1535.

(90) D.T.J.Hurle and E.R.Pike : J.Mater.Sci., 1 (1966), 399.

(91) M.B.Panish : J.Phys.Chem.Solids, 27 (1966), 291.

(92) M.B.Panish: J.Less-Common Metals, 10 (1966), 416.

(93) M.B. Panish : J.Electrochem. Soc., $113(1966)$, 224.

(94) M.B. Panish : J.Electrochem. Soc., 114 (1967), 516.

(95) M.B. Panish and S.Sumski : J.Phys. Chem. Solids, $30(1969), 129$.

(96) M.B.Panish, R.T.Lynch and S.Sumski : Trans. AIME, 245 (1969), 559.

(97) N.J.Olson and G.W.Toop : Trans. Met. Soc. AIME, 245 (1969), 905.

(98) G.B.Stringfellow and P.E.Greene : J.Phys. Chem. Solids, 30 (1969) , 1779.

(99) I.Ansara, P.Desre and E.Bonnier : J.Chim. Phys., 66 (1969) , 297.

(100) M.B.Panish : Phase Diagrams, Vol.III, Ed.by A.Alper, Academic Press, New York, (1970), 53.

(101) I.Ansara, P.Desre and E.Bonnier : C.R.Acad Sci., $270(1970), 1098$.

(102) ref. (77)

(103) G.A.Antypas : J.Electrochem. Soc., $117(1970)$, 700 .

(104) G.A.Antypas : J.Appl.Phys., 41 (1970) , 2165

(105) A.W.Mabbitt : J.Mater.Sci., 5 (1970), 1043.

(106) G.B.Stringfellow: J.Electrochem.Soc., 117 (1970), 1301.

(107) A.S.Jordan : Met.Trans., 2(1971), 1959, 1965.

(108) ref. (82) 
(109) J.F.Counsell, E.B.Lees and P.J.Spencer : Metal Sci. J., 5 (1971), 210.

(110) K.Osamura, J.Inoue and Y.Murakani : J.Electrochem. Soc., $119(1972), 103$.

(111) T.Y.Wu and G.L.Pearson : J.Phys. Chem. Solids, 33 (1972) , 409.

(112) G. B. Stringfellow : J. Phys. Chem. Solids, 33 (1972), 665 .

(113) J.F. Counsell, E.B. Lees and P. J. Spencer : International Symposium on Metallurgical Chemistry, England, (1971) .

(114) I.Ansara : ibid.

(115) G.Kirchner, G.Larbo and B.Uhrenius : Untersuchung der Verteilung von Chrom und Mangan zwischen Ferrit und Austenit mittels experimenteller Messungen und thermodynamishen Berechnungen, to be published.

置換型 4 元合金 $(\mathrm{Pb}-\mathrm{Cd}-\mathrm{Zn}-\mathrm{Sn})$

(116) ref. (109)

侵入型 2 元合金 $(\mathrm{Fe}-\mathrm{C})$

(117) ref. (5)

(118) 竹内：金属学会誌, B-14 (1950), 1.

(119) ref.(6)

(120) L. Kaufman, S. V. Radcliffe and M. Cohen : Decomposition of Austenite by Diffusional Processes, (1962), 313.
(121) H.I.Aaronson, H.A.Domian and G.M.Pound : Trans. Met. Soc. AIME, 236 (1966), 753.

(122) Т. Л. Ершова и И.А. Корсунская : Извес. Акад.Наук СССР, Метвллы, №. 4 (1970), 150.

(123) H.Harvig : Jernkont.Ann., 155(1971), 157.

侵入型 3 元合金 $(\mathrm{Fe}-\mathrm{C}-\mathrm{X})$

(124) E.Rudy : Z.Metallk., 54 (1963), 112, 213.

(125) H.I.Aaronson, H.A.Domian and G.M.Pound : Trans.Met.Soc.AIME, 236 (1966), 768.

(126) T.Nishizawa : Thermodynamic Study of Fe-C$\mathrm{Mn}, \mathrm{Fe}-\mathrm{C}-\mathrm{Cr}$ and Fe-C-Mo Systems, Report 4602, (1967), Swedish Board for Technical Development.

(127) 西沢 : 鉄鋼中の炭化物, No.16(1966), 10.

(128) M.Hillert : Phase Transformations, Ed.by M. Cohen, ASM, Cleveland, Ohio, (1969), 181.

(129) J.Fridberg and M.Hillert: Acta Met., 18(1970), 1253.

(130) H.Harvig, T.Nishizawa and B.Uhrenius : International Symposium on Metallnrgical Chemistry, England, (1971).

(131) T.Nishizawa : Scad.J.Met.,1 (1972) , 41.

(132) T.Nishizawa and B.Uhrenius: Thermodynamics and Phase equilibria of The Fe-Mn-C System; to be published.

\section{• 新技術の開発}

\section{新しいステンレス鋼の登場}

最近，耐食性の優れた高純度高クロムステンレス鋼が 開発されて話題になっている。これは東北大学金属材料 研究所の音谷, 下平両教授の共同研究によるもので, 特 飞孔食のような局部腐食飞強いといわれる，新ステンレ ス鋼の特許範囲は $\mathrm{Cr} 25 \sim 38 \%$, Mo 0.5 $5 \%, \mathrm{Ni} 0 \sim 5 \%$, $\mathrm{Cu} 0 \sim 3 \%, \mathrm{C} 0.02 \%$ 以下となっている.

ステンレス鋼の発展を歴史的にたどるとまず $13 \mathrm{Cr}$ 系統のフェライト系ステンレス鋼に始まるが，1912年 にはE.Mauer と B.Strauss(ドイツ)によって, 初めて $\mathrm{Fe}-\mathrm{Ni}-\mathrm{Cr}$ オーステナイト系ステンレス鋼が開発される におよんで，耐食性は飛躍的に向上した，その後いろい ろの改良が試みられたが, 強さに対する要求は, さらに 析出硬化型 $\mathrm{pH}$ ステンレス鋼を生む機縁となった。近年 になって応力腐食割れが世界的に問題になるにつれて,

これに強い鋼種として $\alpha, \gamma$ 共存の 2 相ステンレス鋼が 登場した。したがって今回話題になっている新しい鋼種 が孔食, 応力腐食割机などに抵抗性が大きいとすれば, 耐食合金としては第 5 のステンレス鋼ということになる かも知れない。

もちろん高クロム鋼の優れた耐食性は従来よく知られ ていた，有名な Tammann の耐食性に関する $\mathrm{n} / 8$ モル
則に照らしても， Cr $26 \%$ 以上になれば耐食性は飛躍的 に向上するはずである。この鋼種が工業的に用いられな かったのは，次のような欠点があるからである。つまり （1）不純物があるために脆くて，加工が困難なこと， (2) 炭素量が多いと粒界腐食を起こすこと，（3)結晶が 粗大化して，機械的性質が悪いことである．新しいステ ンレス鋼では，この欠点を克服するために，溶解の際， 金属 $\mathrm{Ca}$ を添加して脱酸, 脱炭, 脱硫を行ならといわれ る.この不純物除去の反応機構はまだ十分には解明され ていない上らであるが,ともかく,この方法で $\mathrm{C} 0.001 \%$, O 0.005\%, S 0.010\%, N 0.007\%, P 0.004\% 程度にまで 不純物が減少するという。こうして高クロム鋼の最大の 難点である脆さが克服され，王延が容易になるようであ る. 特許の組成範围では $5 \% \mathrm{FeCl}_{3}$ (室温)溶液中でも孔 食は起こらず，沸騰 $\mathrm{MgCl}_{2}$ 溶液中でも応力腐食割れが 起こりにくいといわ杴る.

なお，この鋼種と同じ高純度高クロムステンレス鋼 は，すでに商品名“E-Brite $26-1$ ” (26\% Cr-1\% Mo) と して知られている.ただ，これは Airco Company(アメ リカ)が電子ビーム溶解法を用いて開発したもので, 製 造法が特殊なために量産に難点がある。この点, 日本の 新しいステンレス鋼では普通の電気炉溶解法を用いるの で，量産の可能な点が有望である，問題は均一な製品を 大量に得られるかどらかといらことであるう。

(名古屋工業大学金属工学科 大谷南海男) 